\title{
MAMA AXILAR EM HOMEM
}

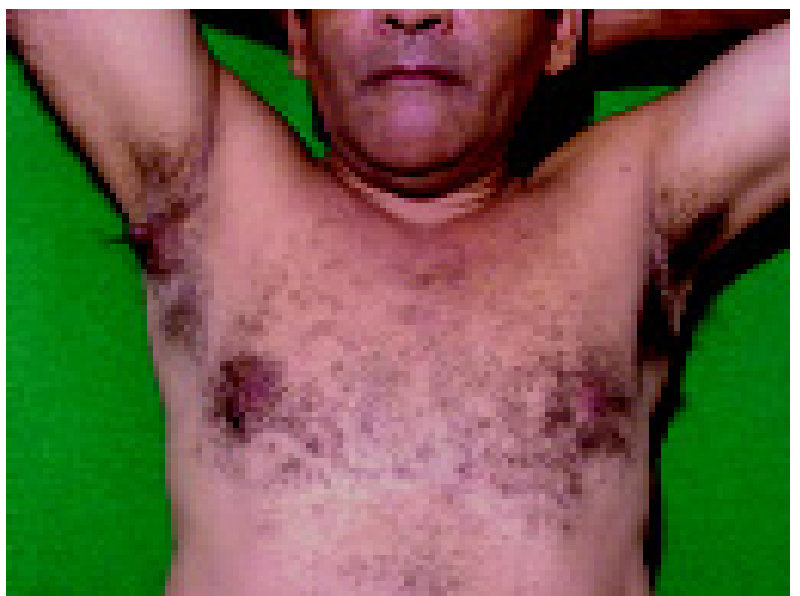

A ocorrência de mama extranumerária completa é um evento raro, principalmente em homens. $O$ tecido mamário ectópico está sujeito às mesmas alterações que ocorrem na mama normoimplantada e pode estar associado a malformações urológicas ou urogenitais.

Paciente, 50 anos de idade, referia que desde a adolescência notou aumento de volume na axila direita. Ao exame físico apresentava mama axilar direita (papila e parênquima mamário). Não apresentava nenhuma outra anormalidade ao exame clínico. Foi proposto a ressecção cirúrgica da mama axilar pela queixa estética, entretanto o paciente não retornou para a cirurgia.

\section{Sabas Carlos Vieira}

\section{Antônio Fortes de Pádua Fillo}

\section{Departamento de Clínica Geral da Universidade Federal do Piauí}

\section{Referências}

I. BoivinS, Segard M, Delaporte E, Cotten H, Piette F, Thomas P. Sein surnuméraire complet de la cuisse chez um homme. Ann Dermatol Venerol 200I; I28(2):I33-6.

2. Leung W, Heaton JP, Morales A. An uncommon urologic presentation of a supernumerary breast. Urology 1997;50(I):122-4. 